\title{
LA ICONOGRAFÍA DE LAS BANDERAS DE CARLOS V: EJEMPLOS Y NOTICIAS DOCUMENTALES*
}

\author{
Jesús F. Pascual Molina ${ }^{1}$ \\ Universidad de Valladolid
}

\begin{abstract}
El emperador Carlos V agrupó un importante conjunto de armas y armaduras en Valladolid. Con motivo de su último viaje a España en 1556, nuevas piezas se incorporaron a la armería imperial que pasó después de su muerte a Felipe II, quien la trasladó a Madrid, donde se construyó un edificio destinado a contener la colección. Entre ellas destacó un importante grupo de banderas ligadas a episodios singulares de la vida del emperador. Describimos el conjunto y su iconografía, aportando además noticias de archivo inéditas, que permitirán conocer mejor las banderas empleadas en tiempos del César Carlos y el significado que se las otorgó.
\end{abstract}

Palabras clave: banderas; Carlos V; Real Armería.

\section{THE ICONOGRAPHY OF THE FLAGS OF CHARLES V: EXAMPLES AND DOCUMENTS}

The Emperor Charles V formed an important group of arms and armor in his armory at Valladolid. In 1556, during his last journey to Spain, new pieces were sent to this royal armory; after his death they passed to Philip II, who sent them to Madrid, where he ordered a new building especially for the collection. Among these pieces was an important group of flags linked to major episodes of the Emperor's life. The author describes the flags and their iconography, providing as well unpublished archival materials, which permit a better understanding of the flags used in times of Caesar Charles and their meanings.

Key words: flags; Charles V; Royal Armory.

Como citar este artículo/Citation: Pascual Molina, Jesús F. (2017): "La iconografía de las banderas de Carlos V: ejemplos y noticias documentales". En: Archivo Español de Arte, vol. 90, núm. 357, Madrid, pp. 31-48; doi: 10.3989/ aearte.2017.03.

Desde la Antigüedad el uso de banderas, enseñas y guiones, ha servido para identificar territorios, instituciones o personalidades, así como para agrupar tropas en la guerra². Su uso simbólico y propagandístico ha sido siempre innegable, lo que ha convertido a la bandera en portadora de un especial significado, transformándola en ocasiones en fetiche y reliquia de hechos y sucesos de importancia. Así por ejemplo, en los triunfos militares se incluían las banderas capturadas al enemigo, y en los funerales representaban territorios y posesiones, y aun al propio finado, en una suerte de sustitución simbólica.

* Trabajo realizado en el marco del Proyecto de Investigación del Ministerio de Economía y Competitividad de España, HAR2013-41053-P Arte y lujo. Valoración y presencia de los tapices flamencos en España en los siglo XV y XVI y su fortuna posterior. El autor es miembro del Grupo de Investigación Reconocido Arte, poder y sociedad en la Edad Moderna de la Universidad de Valladolid.

1 pascual@arte.uva.es / ORCID iD: http://orcid.org/0000-0002-8779-5752.

2 Un interesante estudio, en especial su uso en la Edad Media y el Renacimiento: Wescher, 1949: 2806-2830. 
Durante el siglo XVI en el entorno de los Habsburgo, por continuidad con los usos y costumbres borgoñones, se percibe un uso constante de la ornamentación heráldica y el empleo de banderas en las ceremonias y actos cortesanos, con clara intención de consolidar la imagen del soberano.

\section{Antecedentes}

En el ducado de Borgoña la heráldica adquirió suma importancia especialmente en la construcción de la imagen del poder, "pues era la expresión simbólica y visual del linaje y los territorios"3. Los duques emplearon con asiduidad las armas del ducado, pero sus banderas aumentaron en riqueza iconográfica tras la aparición de la orden del Toisón de Oro. Cuando Felipe el Bueno la fundó en 1430, la puso bajo la advocación de Nuestra Señora y San Andrés, patrón de Borgoña y del que se conservaban diversas reliquias desde tiempos de las Cruzadas, y que habría sido el evangelizador de esas tierras según una leyenda originada en tiempos del duque Felipe el Atrevido ${ }^{4}$. Desde entonces el santo aparecerá de forma recurrente en las banderas del ducado junto con la cruz en aspa de su martirio, que en ocasiones lo hace en solitario, representando no sólo al santo sino convirtiéndose en símbolo del propio ducado y de la citada Orden. Además de las aspas de Borgoña, eslabones, pedernales y llamas -en alusión a los símbolos del Toisón de Oro-, sobre campos de diferentes colores y acompañados de los motes y lemas de los duques, constituirán el repertorio ornamental de las enseñas borgoñonas.

Cuando Carlos el Temerario reorganizó sus ejércitos en la década de 1470, las banderas adquirieron gran importancia. Podía distinguirse entre bandera, fundamentalmente heráldica y de forma rectangular; estandarte, de forma triangular, con imágenes de santos y el mote del duque; y cornetas, que en Borgoña eran rectangulares, con imágenes de santos enmarcadas en un cuadrado, acompañadas del mote personal del duque ${ }^{5}$. Entre los objetos del botín capturado por los suizos en las batallas de Grandson, Morat y Nancy $(1476)^{6}$, figuran el estandarte de Borgoña que mostraba las armas del ducado, así como algunas banderas con decoración alusiva a los emblemas del territorio y el mote Je l'ay emprins empleado por el duque, y diferentes santos protectores de las compañías de soldados, como San Jorge, San Bartolomé, Santo Tomás, San Judas, Santiago, San Juan, San Pedro, Santa Catalina o la Magdalena, entre otros 7.

Aún hoy poseemos algunos ejemplares de estas banderas ${ }^{8}$. Así, en el Kantonales Museum Altes Zeughaus de Solothurn, se conservan un fragmento de estandarte con la figura de San Juan y los símbolos de la orden del Toisón de Oro ${ }^{9}$, o una pieza capturada en la batalla de Grandson y probablemente perteneciente a la guardia personal del duque, con la imagen de San Jorge, su santo patrón (fig. 1) ${ }^{10}$. Los restos conservados permiten afirmar que se alcanzó una gran calidad en lo que a la pintura ornamental se refiere.

\footnotetext{
3 Domínguez Casas, 2006: 96.

${ }^{4}$ La relación de Borgoña con San Andrés en Boulton, 2006: 21-97. En p. 67, la referencia a las reliquias y la citada leyenda.

${ }^{5}$ Marti, 2009: 324. En sus Mémoires, Olivier de La Marche describe el uso y apariencia de las banderas ducales, aportando muchos datos sobre su función y otros detalles. Por ejemplo sobre la bandera y el estandarte, La Marche, 1888: 60 .

${ }^{6}$ Sobre este botín, Deuchler, 1963. Mäder/Heinz, 1969: 89-166. La importancia que los suizos dieron a lo capturado a los borgoñones -en especial las banderas- fue enorme, estableciéndose un auténtico culto a estas reliquias.

7 Michael/Embleton, 1983: 34-36. Wescher, 1949: 2829. Mäder/Heinz, 1969: 98-166.

8 Sobre la conservación y restauración de las banderas borgoñonas, Senn, 1994, y Mäder, 1994.

9 Número de inventario MAZ 1135. Fechado en 1476, procedente del botín de la batalla de Grandson, muestra la imagen de San Juan Evangelista sentado en un trono, sosteniendo la copa ponzoñosa que le sirve de atributo, enmarcado en un cuadrifolio dorado. La ficha de la pieza en la web del museo: http://emp-web-45.zetcom.ch/eMP/eMuseumPlus.

10 Número de inventario MAZ 1145. Fechado hacia 1474, muestra la superficie dividida en dos franjas, la superior blanca y la inferior azul. En el lado del asta, San Jorge lucha contra el dragón, mientras el resto de la superficie apare-
} 


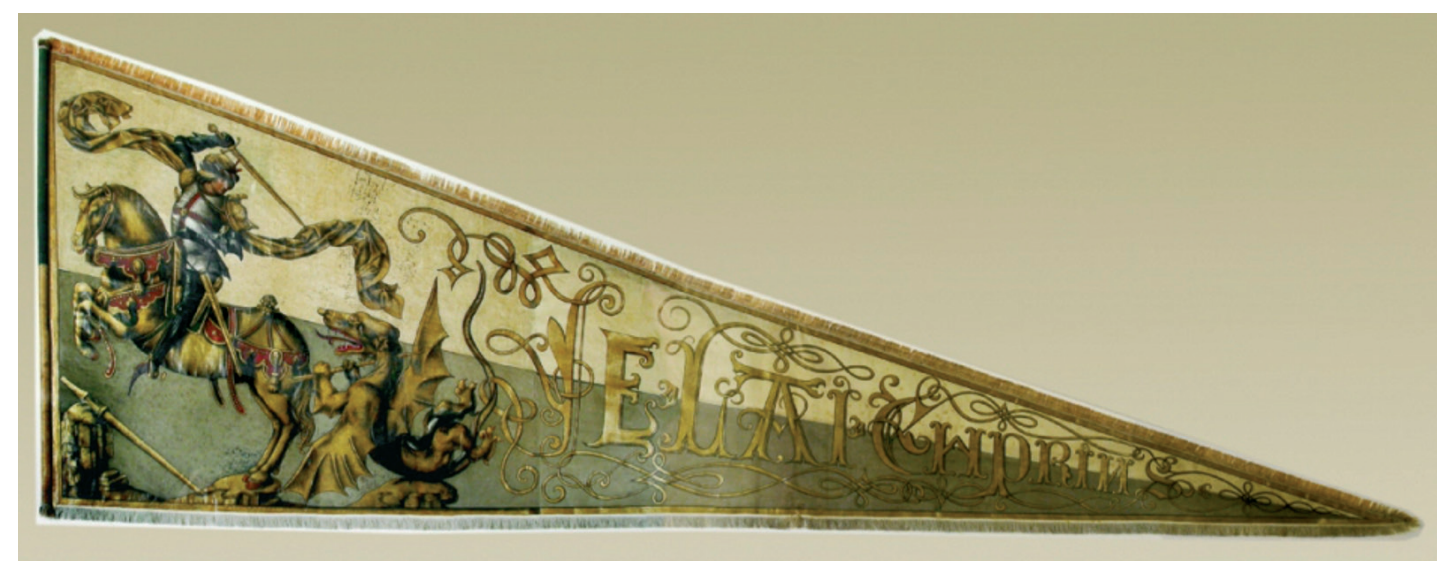

Fig. 1. Estandarte de San Jorge. 1474. Kantonales Museum Altes Zeughaus de Solothurn (Suiza). Inv. MAZ 1145.

Además de en la guerra, el despliegue de banderas alcanzaba gran importancia en la celebración de funerales ${ }^{11}$. Esta tradición se remontaba al menos al siglo XIV, y servía fundamentalmente para mostrar los dominios del difunto así como su dignidad. En 1473, con motivo del traslado de los cuerpos de Felipe el Bueno e Isabel de Portugal desde sus enterramientos originales a Dijon decretado por Carlos el Temerario, el funeral fue codificado en una ordenanza que recogía los pormenores de la ceremonia, entre los que se incluían las banderas de los cuatro dominios del difunto, así como el pendón y la bandera ducales ${ }^{12}$.

Si bien el emperador Maximiliano I -duque de Borgoña por matrimonio con la duquesa María y jefe de la orden del Toisón de Oro- empleó enseñas semejantes a las usadas por Carlos el Temerario, dada su dignidad imperial desde 1508 -fecha de su proclamación como emperador electo- se hizo acompañar de banderas con iconografía alusiva a tal rango, como el águila bicéfala de sable en campo de oro, que se vinculaba a la Antigüedad y se recuperó en la Edad Media ${ }^{13}$, siendo empleada como símbolo imperial desde Segismundo de Luxemburgo a comienzos del siglo XV. Este emblema se complementó con la presencia de un escusón partido con las armas de Austria y Borgoña. Así se puede ver, por ejemplo, en algunos detalles del Arco de triunfo del emperador Maximiliano I, realizado entre otros por Alberto Durero hacia $1515^{14}$. También en el Carro triunfal ${ }^{15}$, obra de Albrecht Altdorfer y su círculo entre 1513 y $1515^{16}$, podemos ver varias banderas, tanto la del águila bicéfala como las armas de Austria -tres franjas horizontales, la superior e inferior de gules, la central de plata- y los símbolos del Toisón de Oro, aludiendo a la dignidad imperial, los dominios austríacos y Borgoña. Estas dos obras formaban parte de un conjunto de empresas artísticas llevadas a cabo por el emperador, destinadas fundamentalmente a perpetuar su memoria ${ }^{17}$.

La heráldica alusiva a las posesiones territoriales patrimoniales nunca faltaba, conviviendo con las enseñas de carácter simbólico. Cuando en 1519 se celebraron las exequias por el empe-

ce decorada con el mote "Je lay emprins", en caracteres dorados ornamentados con complejas filigranas, separadas las palabras por pedernales alusivos a la orden del Toisón. La ficha en: http://emp-web-45.zetcom.ch/eMP/eMuseumPlus

${ }^{11}$ Domínguez Casas, 2010: 260.

12 Domínguez Casas, 2010: 263.

13 Wescher, 1949: 2812.

14 Schauerte, 2001.

15 Una copia de comienzos del siglo XVII en Biblioteca Nacional de España (BNE), Res/254.

16 Madersbacher, 1992b: 454-455.

17 Schütz, 1992: 233-251, en especial 246-248. 
rador Maximiliano en la catedral de Barcelona, en la procesión fúnebre se emplearon "XXI banderas cada una en su orden adonde la ynperial era la postrera" 18 . Dieciséis eran "todas de las provinçias que tocan al archiducado de Austria", además de las banderas de Croacia, Austria, Hungría y Dalmacia, siendo la última "la gran bandera ynperial", que como la gualdrapa del caballo y la cota de armas del difunto, eran "de muy rico brocado adornados de las armas imperiales"19.

En su viaje a España en 1506, Felipe el Hermoso se hizo acompañar de un numeroso séquito, incluyendo un contingente militar que empleó banderas siguiendo la tradición de los duques de Borgoña ${ }^{20}$, especialmente aspas de San Andrés, eslabones, pedernales y llamas, como podemos ver en la pintura atribuida a Jacob van Laethem del Encuentro de Felipe el Hermoso y Fernando el Católico en Remesal, conservada en el Château de la Follie (Ecaussinnes, Bélgica) ${ }^{21}$.

Junto a estos símbolos, en tiempos de Felipe el Hermoso se emplearon también enseñas heráldicas con las armas partidas de Castilla y Aragón, y Borgoña; y el guión de la banda -de gules, una banda de oro con tragantes- empleado por los reyes de Castilla, pues tal era su condición desde 1504 en tanto que esposo de Juana $\mathrm{I}^{22}$. Ejemplos del guión real pueden verse en los conservados en la Capilla Real de Granada ${ }^{23}$.

En España los Reyes Católicos también usaban las banderas como símbolos de su poder y referente de su presencia. Tradicionalmente en Aragón se empleaba la enseña de cuatro palos de gules sobre fondo de oro, y en Castilla la bandera cuartelada de castillos y leones como la descrita en el inventario de los objetos custodiados en el alcázar de Segovia en 1503:

Un pendón real grande de tafetán blanco e encarnado, fecho a quarterones, los leones en campo blanco son fechos de tafetán colorado e todo bordado de oro hilado e los castillos amarillos e las puertas azules, tiene en ancho seys varas e de largo ocho varas escasas, e las flocaduras anchas de seda colorada e blanca, tiene unas cintas de seda blanca e colorada, con unas perillas e borlas al cabo de la dicha seda ${ }^{24}$.

Isabel y Fernando emplearon las armas cuarteladas de Castilla y Aragón -primer y cuarto cuarteles, cuartelados de castillos y leones; segundo y tercer cuartel, partidos de Aragón y Sicilia-. Con motivo de las ceremonias fúnebres celebradas por el príncipe don Juan en Bruselas en 1498, se emplearon banderas con las armas de los diferentes reinos de la Península Ibérica: cuarteladas de Castilla y León, Aragón, partidas de Aragón y Sicilia, y Granada, así como una "banniere des pleines armes despaigne" 25 .

Sin embargo, existieron banderas más complejas. Ya se ha citado la existencia del guión real de la banda, empleado en Castilla desde tiempos de Alfonso XI para señalar la presencia del soberano en el campo de batalla, en la liza, o allí donde este se encontrara ${ }^{26}$. En el tesoro del alcázar de Segovia se custodiaban junto a objetos de plata, armas y símbolos del poder regio,

18 BNE, manuscritos, MSS/11423, fol. 247 (foliación moderna). El manuscrito contiene diversos escritos de Garci Alonso de Torres, rey de armas de nombre Aragón, agrupados bajo el título de Espejo de nobleza, tratado heráldico escrito por este oficial.

19 BNE, manuscritos, MSS/11423, fol. 247 (foliación moderna).

20 Domínguez Casas, 1993: 678 y 684.

21 Zalama/Domínguez Casas, 1995: 347-358.

22 Domínguez Casas, 1993: 677-678.

23 Eisman Lasaga, 1994: 169.

${ }^{24}$ Libro de cosas que están en el tesoro de los Alcázares de Segovia, 1503-1511, Archivo General de Simancas (AGS), Patronato Real (PR), legajo 30, doc. 6, fol. 29 v. El inventario de lo custodiado en Segovia en Ferrandis Torres, 1948: 69-169. Sobre la bandera real, Nieto Soria, 1993: 201-205.

25 Domínguez Casas, 2010: 268.

26 Domínguez Casas, 1993: 677-678. 
diversas banderas ${ }^{27}$, incluyendo el pendón real antes descrito así como otras con variada iconografía, como un pendón de tafetán colorado "en que está Santiago pintado de ambas partes a cavallo, las flocaduras de seda blanca e negra" 28 , o las que mostraban las divisas del rey Juan II y Enrique IV, en desuso en el reinado de los Reyes Católicos ${ }^{29}$. La introducción de la figura de Santiago - patrón de España- fue frecuente en los ejemplares del momento. Así, junto a las banderas que se custodiaban en el alcázar de Segovia, tenemos noticia también de una que llevó la flota enviada en 1500 a combatir contra los turcos en Grecia, y que era de seda y lienzo con "un Santiago dorado con un campo colorado e una cruz blanca"30.

Carlos $\mathrm{V}$, heredero de los territorios y tradiciones borgoñonas por vía paterna así como de los reinos de Castilla y Aragón por vía materna, aunará símbolos y emblemas sin dejar de hacer un uso intensivo de la heráldica como elemento propagandístico de importantísimo alcance.

\section{Iconografía en las enseñas de Carlos V}

La elección tanto de los motivos como de los colores de las banderas no era casual. Cuando en noviembre de 1517 Carlos V llegó a Valladolid, el joven rey vestía "un coselete de acero, muy reluciente, con el gorgorín, antebrazo y arnés de pierna, habiéndose puesto, por encima de ese coselete, un rico sayo de sus colores, amarillo, blanco y rojo, por mitades" ${ }^{31}$. Asimismo, entre las banderas que formaban parte de la armería imperial custodiada en Valladolid, se encontraban: una "bandera grande de tafetán amarillo, colorado y blanco, adonde está pintado Santiago", "Otra bandera grande de tafetán amarillo, colorado y blanco y en ella está pintado San Xpval", "Otra bandera pequeña de tafetán amarillo, blanco y colorado, adonde esta pintado un Sant Andrés" y "otra bandera quadrada de damasco negro, con las armas del emperador, frangeada de colorado, amarillo y blanco" 32 . Mientras el rojo y el blanco eran colores empleados en Austria, en Castilla y Aragón se empleaban el rojo y el amarillo. En la corte de Carlos V se supo combinar ambas preferencias.

Las figuras religiosas eran recurrentes en la decoración de banderas. Así, aparecían Nuestra Señora o el crucifijo, pero sin duda los santos adquirieron especial protagonismo. Se puede hablar de una herencia iconográfica fundamentada en los santos protectores de la monarquía hispánica, así como de Borgoña y de la casa de Austria. Son recurrentes las figuras de San Andrés y Santiago - patronos respectivamente de Borgoña y la corona española-, y también San Jorge, que aparecen constantemente entre la iconografía de las banderas del emperador. San Andrés y Nuestra Señora son además las advocaciones bajo las que se fundó la orden del Toisón de Oro y su presencia supone una continuidad de la iconografía borgoñona.

Santiago se empleaba por su carácter de patrón de España, así como por ser imagen del guerrero cristiano defensor de la $\mathrm{fe}^{33}$. En las banderas carolinas aparece a caballo, luchando contra los infieles, recordando el episodio de la batalla de Clavijo, frente a la iconografía del peregrino, con sombrero, zurrón y bordón, que se repite en las banderas ducales de Borgoña ${ }^{34}$. Siguiendo la tradición, Carlos V usará también banderas ornamentadas con la figura del apóstol, y en los funerales que por él se celebraron en Bruselas en 1558 se empleó el Grand estandart des couleurs, que junto a la divisa del Plus Oultre y los símbolos del Toisón, mostraba un Santiago a caballo

27 Libro de cosas que están en el tesoro de los Alcázares de Segovia, 1503-1511, AGS, PR, leg. 30, doc. 6, fol. 29, "Guiones e banderas e pendones".

${ }^{28}$ Libro de cosas que están en el tesoro de los Alcázares de Segovia, 1503-1511, AGS, PR, leg. 30, doc. 6, fol. 29 v.

29 Fernández de Córdova, 2012: 22-37.

30 Domínguez Casas, 1993: 677.

31 Vital, 1952: 706.

32 Apéndice documental, documento 1.

33 Nieto Alcaide/García Morales, 2004: 33-51.

34 Por ejemplo así aparece en el ejemplar conservado en Dijon. Mäder/Heinz, 1969: 158-159. 


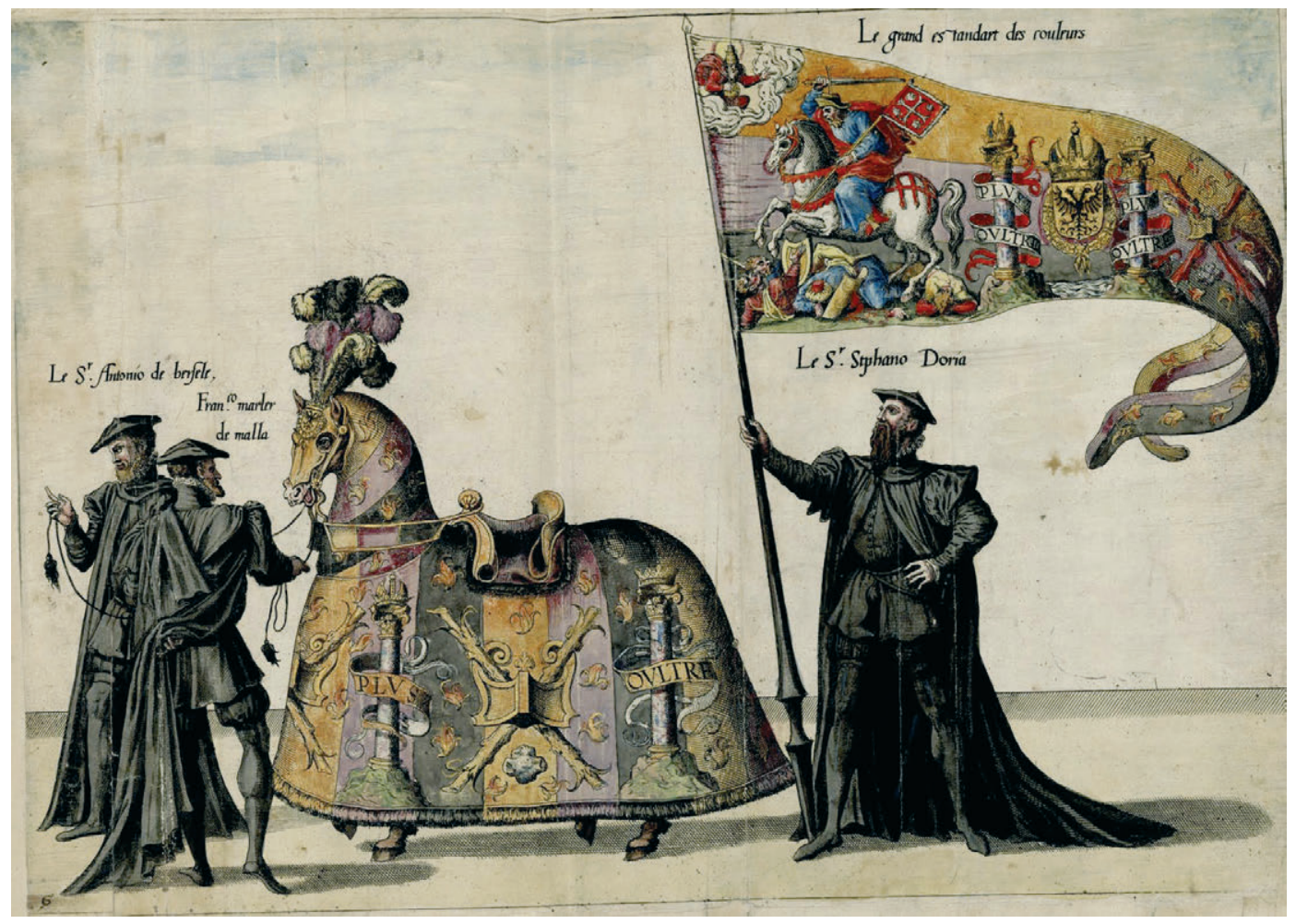

Fig. 2. Grand estandart des couleurs. Detalle de La magnifique et sumptueuse pompe funèbre faite aus obseques et funerailles du tresgrand et tresvictorieus empereur Charles cinquième..., Amberes, 1559.

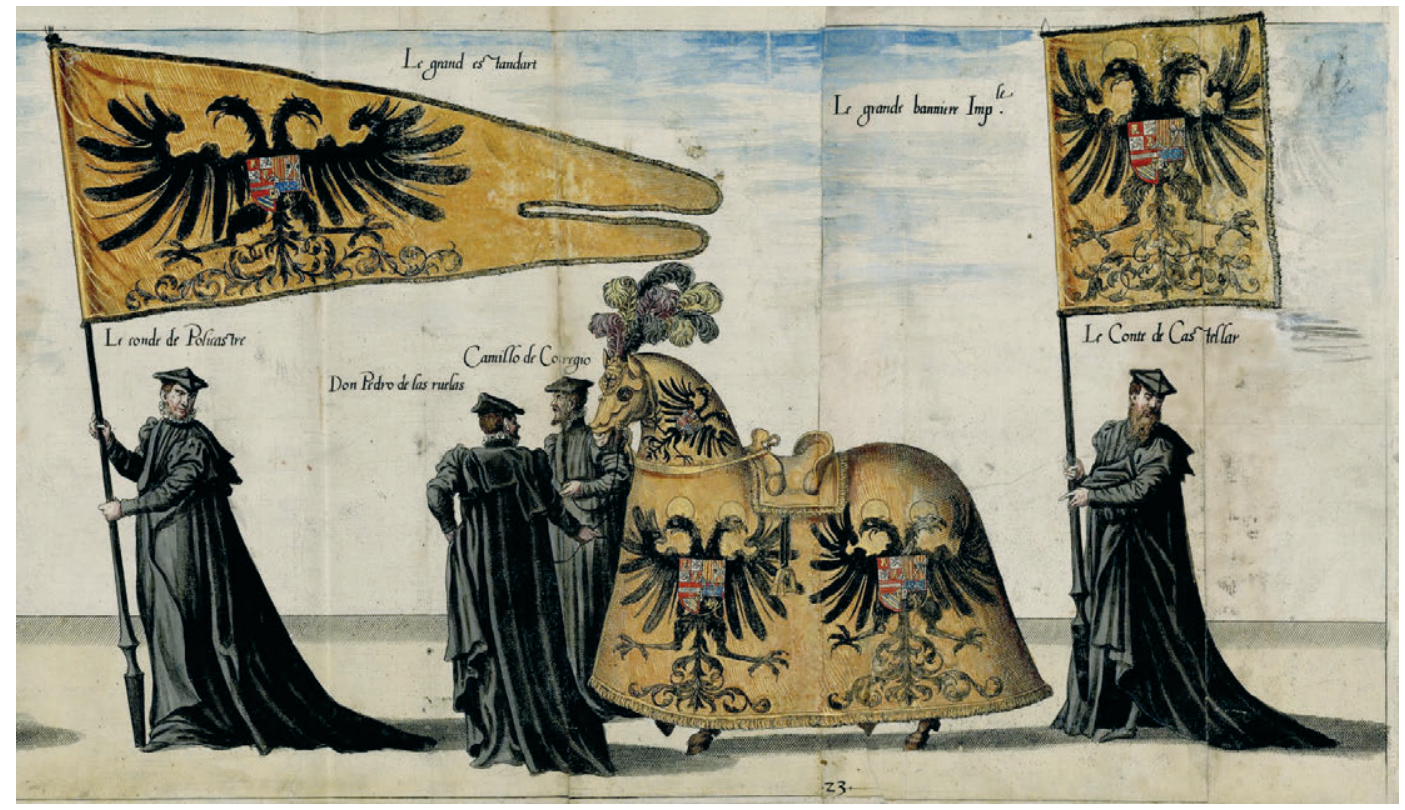

Fig. 3. Le grand estandart y Le grande banniere imperiale. Detalle de La magnifique et sumptueuse pompe funèbre faite aus obseques et funerailles du tresgrand et tresvictorieus empereur Charles cinquième..., Amberes, 1559. 
blandiendo su espada, como puede verse en la serie de estampas que los Doetecum realizaron en 1559 (fig. 2) ${ }^{35}$.

Es importante también la presencia de San Jorge en las banderas imperiales. El santo estaba relacionado con la caballería, era patrón de los cruzados y personal del duque Carlos el Temerario, y a él estuvo vinculado Federico III, que en 1467 había fundado la orden de caballería de San Jorge. Esta devoción fue heredada por su hijo Maximiliano I, quien además de proteger la orden creada por su padre, fundó en 1494 la Confraternidad de San Jorge ${ }^{36}$. Desde Carlos el Temerario era frecuente que el duque apareciera vinculado al santo, no sólo bajo su protección sino con la apariencia del mismo, como ocurre en el excepcional relicario de la catedral de San Lamberto en Lieja ${ }^{37}$. También Maximiliano aparece ligado al santo en diversas obras de arte: fue sepultado en la capilla dedicada al santo en Wiener Neustadt ${ }^{38}$, y gustaba de representarse como él y asociar su imagen a la del miles Christi, que en aquel momento encarnaba perfectamente los valores de cruzada y defensa contra el turco ${ }^{39}$. Y lo mismo ocurrió con su hijo Felipe el Hermoso, que aparece como San Jorge en algunas imágenes ${ }^{40}$. Por otro lado, no podemos olvidar además que el santo, devoción particular de los reyes de Aragón, terminó por convertirse en el patrón del reino ${ }^{41}$. En las ceremonias de las coronaciones de Aquisgrán y Bolonia, y en la campaña de Túnez, se documenta la presencia de banderas con esta iconografía como veremos.

Junto a esta decoración figurativa de carácter religioso, la heráldica era un motivo omnipresente en las banderas. Las armas imperiales con el águila bicéfala se emplean tras la dignidad imperial y siguiendo un modelo que se remonta a los emperadores Federico III y Maximiliano I: un águila bicéfala de sable sobre fondo de oro, con un escusón en el pecho con las armas personales del emperador (fig. 3). Se usaban también las armas reales de Castilla y Aragón, junto a las de los dominios austríacos y borgoñones.

\section{Banderas de Carlos V: algunos ejemplos}

Son varios los episodios de la vida del emperador en los que las banderas adquirieron un especial protagonismo y como habían hecho sus predecesores, conservó algunos ejemplares de especial significado que se integraron en su colección de la armería ${ }^{42}$, que pasó a Felipe II y tras cuya muerte se convirtió en parte de los bienes vinculados a la Corona como dispuso en su codicilo de 1597. Destacan en este sentido las coronaciones de Aquisgrán (1520) y Bolonia (1530), así como la campaña de Túnez (1535).

En la conocida como Relación de Valladolid -inventario incompleto de los objetos que integraban la armería del emperador en 1558- no aparece la relación de las banderas al haberse perdido esa parte de la documentación, si bien a la luz de nuevas fuentes podemos conocer qué ejemplares permanecían en Valladolid tras la muerte de Carlos $\mathrm{V}^{43}$. Además, un nuevo documen-

${ }^{35}$ La magnifique et sumptueuse pompe funèbre faite aus obseques et funerailles du tresgrand et tresvictorieus empereur Charles cinquième..., Amberes, 1559.

36 Sobre la vinculación del emperador con San Jorge, Wiesflecker-Friedhuber, 1997: 431-454.

37 Koldeweij, 2013: 229.

38 Iglesia del palacio en el que Maximiliano había nacido en 1459, y donde la orden de San Jorge celebraba sus solemnidades. Martínez López, 2013: 489-490.

39 Sirvan de ejemplo la pareja de grabados de Hans Burgkmair realizados en 1508, en la que uno de ellos muestra a San Jorge y el otro al emperador -Pokorny, 1992a: 437-438. Checa, 2007: 398-399-; la estampa grabada hacia 15091510 por el armero Daniel Hopfer -Pokorny, 1992b: 347-; o el relieve, realizado hacia 1525 por Hans Daucher -Madersbacher, 1992a: 436-.

40 Como en la pintura del gremio de ballesteros de Amberes, conservada en el Koninklijk Museum voor Schone Kunsten de esa ciudad, o la escultura de la iglesia de San Jorge en Sint-Joris-ten-Diste, donde el santo luce el collar de la orden del Toisón de Oro. Onghena, 1959: 117-119 y 282-283.

41 Canellas López, 1966-1967: 7-22.

42 Sobre la armería imperial, Pascual Molina, 2013: 81-101.

${ }^{43}$ La relación de banderas en Apéndice documental, documento 2. 
to fechado en 1542 ha permitido conocer el primer registro de las enseñas que el emperador conservó en su armería ${ }^{44}$. Con el paso del tiempo y el deterioro de las banderas se olvidó el origen de las mismas, apareciendo apenas su descripción en los posteriores inventarios y registrándose su última referencia documental a mediados del siglo XVII ${ }^{45}$.

Hoy en día no conservamos más que pequeños fragmentos de aquellas y las imágenes insertas en el denominado Inventario Iluminado ${ }^{46}$, documento fundamental para hacerse una idea de la riqueza iconográfica de unas piezas que han sufrido el paso del tiempo. Reproducidas en él aparecen varias banderas (figs. 4 a 7), que Valencia de Don Juan relacionaba con las representadas en los paños de la serie de la Empresa de Túnez ${ }^{47}$.

El 23 de octubre de 1520 Carlos V fue coronado como rey de romanos en Aquisgrán y proclamado emperador electo tres días más tarde ${ }^{48}$. Diversas fuentes recogen la magnificencia del acto, sus participantes, así como los pormenores de la ceremonia ${ }^{49}$, y en alguna de ellas se dice cómo había "Darnach noch XXX. und ein banner, alle gerüst. Darnach ein baner und iii. lediger hengst mit gülden und silvern barssen" 50 .

Entre las banderas que se custodiaban en la armería de Valladolid había al menos cinco piezas identificadas con su uso en Aquisgrán -Aes en la documentación- durante los actos de coronación del emperador. Eran una "bandera de tafetán amarillo adonde están pintados Sant Andrés, Sant Jorge y Santiago", otra "grande de tafetán amarillo colorado y blanco adonde está pintado Santiago", otra "grande de tafetán amarillo colorado y blanco y en ella está pintado San Xpval", una "pequeña de tafetán amarillo blanco y colorado adonde esta pintado un Sant Andrés" y una "redonda de damasco negro con las armas del emperador", en las que se especifica que fueron hechas para la coronación ${ }^{51}$.

Sabemos que los pintores Alonso Berruguete y Juan de Bruselas cobraron ciertas cantidades por la realización de diversas decoraciones para la flota que partió de La Coruña el 20 de mayo de $1520^{52}$. Tal vez no sólo trabajaron en la nao real, sino que como artífices al servicio de la Corona bien pudieron realizar también las banderas citadas ${ }^{53}$.

Como ocurre con la coronación de Aquisgrán, las fuentes literarias sobre la coronación de Bolonia son muy abundantes ${ }^{54}$, pero de este acto existieron además importantes testimonios gráficos ${ }^{55}$. Todas las crónicas coinciden en algunos aspectos en lo que se refiere a las banderas -que jugaron un importante papel simbólico-, si bien existen pequeñas diferencias como veremos.

Tanto en la entrada en Bolonia efectuada en 1529, como en la cabalgata triunfal posterior a la coronación de 1530, se emplearon banderas de águilas bicéfalas con la heráldica imperial y otros símbolos alusivos a la dignidad del césar. Estuvieron también presentes las banderas de la

${ }^{44}$ Apéndice documental, documento 1.

45 Crooke y Navarrot, 1898: 344-346.

46 Interesantísimo documento, se trata de dos volúmenes incompletos donde están pintados a la acuarela los pertrechos de la armería de Carlos V. Se conserva en la Real Armería de Madrid (con la referencia de inventario N-18) y fue publicado parcialmente en Crooke y Navarrot, 1889: CCCLIII-CCCXCIX; 1890: CCXLII-CCCXXIV.

47 Crooke y Navarrot, 1889: CCCLIV. Las imágenes en las láminas 20 a 23.

48 Heusch, 1960: 161-168.

49 Por ejemplo, Die Triumphe van dat Cronemente van den Keyser..., Amberes, 1520; Römischer Küniglicher Maies. Krönung zu Ach geschehe[n], Augsburgo, 1520; Des allerdurchleuchtigisten vnd grossmechtigiste[n] fursten vnd herren herren [sic] Karls Romischen vnd Hyspanischen Konigs auch kunfftigen Kaysers Einzug yezt zu Ach am. xxij. tag Octobris beschehen gantz lustbarlich vn[d] kurtzweylig zu lesen, Nuremberg, 1520. También se refieren a ella cronistas posteriores como Sandoval, 1604: 284-288.

${ }^{50}$ Beschreibung der einreittung Auch Krönu[n]g des Großmechtigsten Fürsten vn[d] Römischen Könings Caroli des fünfte[n], Mainz, 1520, s/f.

51 Apéndice documental, documento 1.

52 Azcárate, 1988: 15.

53 Azcárate, 1982: 44-45 y 54. Redondo Cantera, 2013: 49-89, las decoraciones de Berruguete para la flota, 66-67.

54 Sin duda la más conocida es la de Agrippa, Caroli Quinti cum Hispaniarum tum duplicis Germaniae et Romanoru[m] Archiregis, utriusq[ue] [et] in Longobardorum regem, [et] in Romanorum Impertorem coronationis historia, Amberes, 1530, s/f. Sobre la coronación de Bolonia y sus fuentes Righi, 2000.

55 Borrás Gualis/Criado Mainar, 2000. Criado Mainar, 2006: 103-117. 


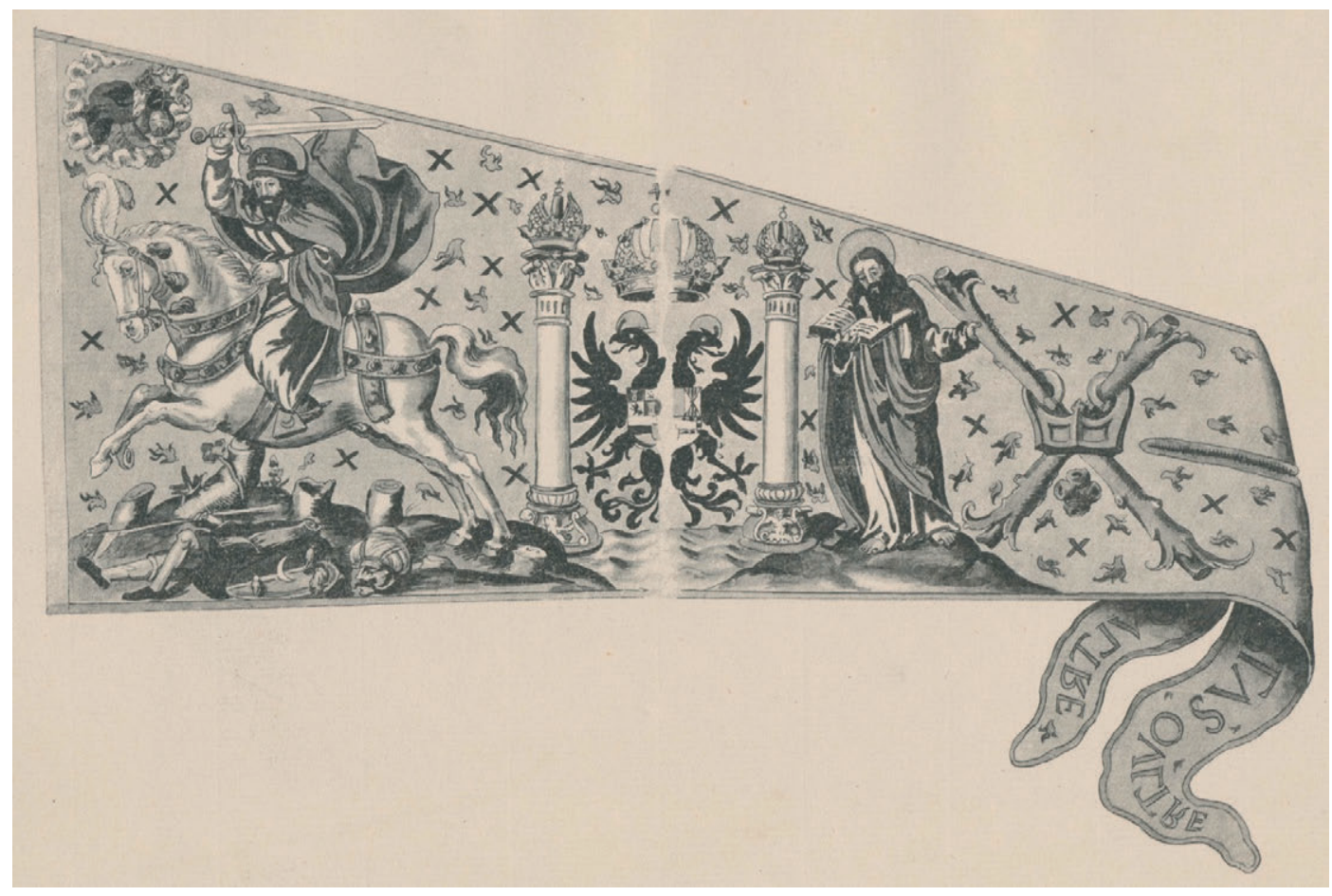

Fig. 4. Bandera de Santiago. Del Inventario Iluminado (Real Armería, Madrid, inv. N-18). Fuente, Crooke y Navarrot, Juan Bautista (conde de Valencia de Don Juan) (1889): "Bilderinventar der Waffen, Rüstungen, Gewänder und Standarten Karl V. In der Armería Real zu Madrid [1]”. En: Jahrbuch der Kunsthistorischen Sammlungen des Allerhöchsten Kaiserhauses, 10, Viena, pp. CCCLIII-CCCXCIX.

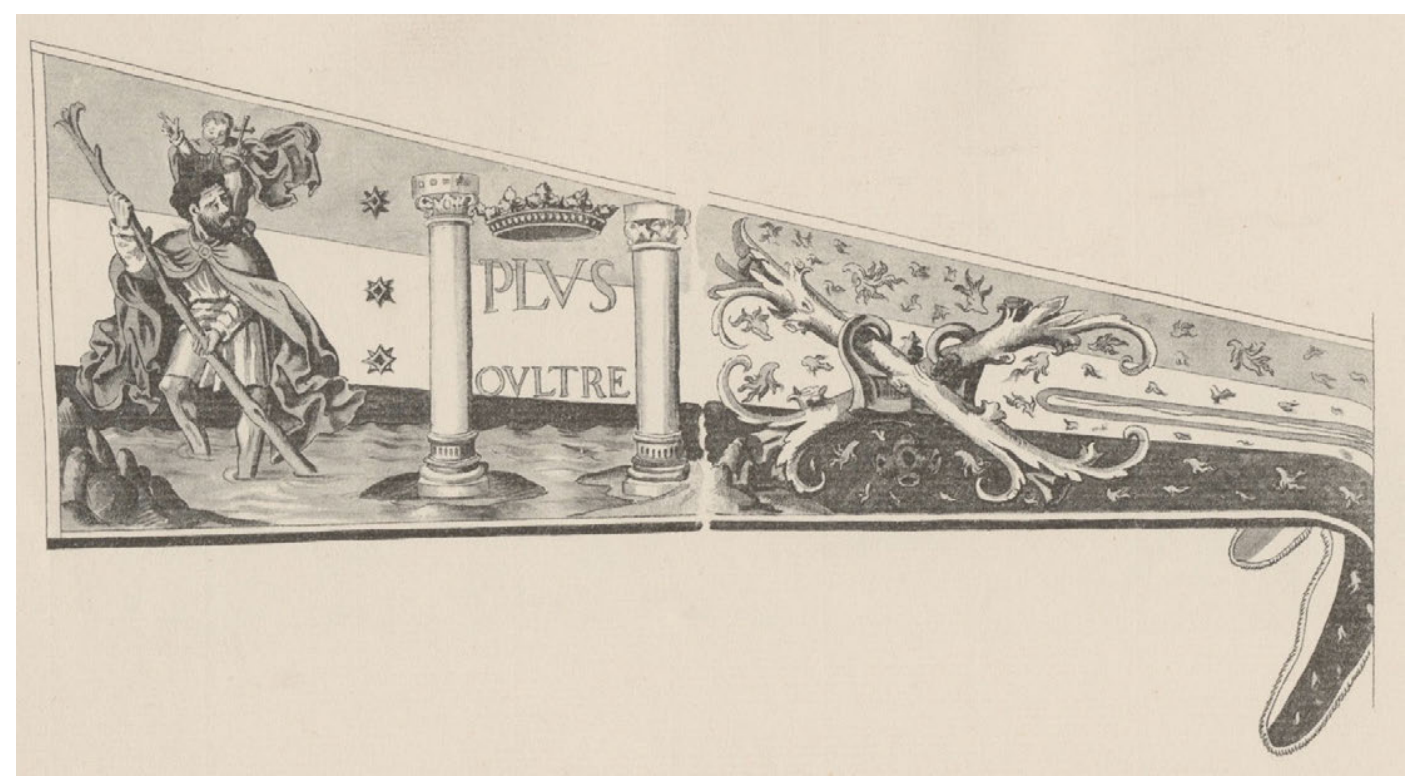

Fig. 5. Bandera de San Cristóbal. Del Inventario Iluminado (Real Armería, Madrid, inv. N-18). Fuente, Crooke y Navarrot, Juan Bautista (conde de Valencia de Don Juan) (1889): "Bilderinventar der Waffen, Rüstungen, Gewänder und Standarten Karl V. In der Armería Real zu Madrid [1]”. En: Jahrbuch der Kunsthistorischen Sammlungen des Allerhöchsten Kaiserhauses, 10, Viena, pp. CCCLIII-CCCXCIX. 


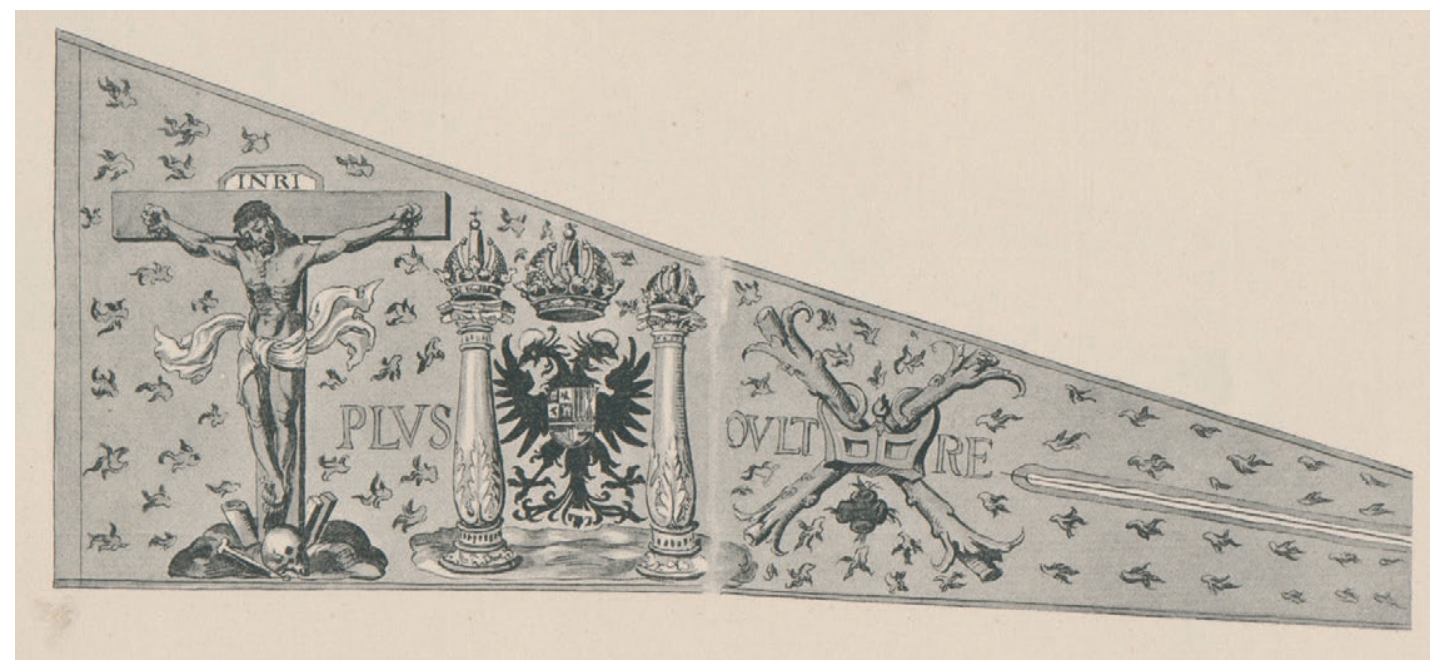

Fig. 6. Bandera del crucifijo. Del Inventario Iluminado (Real Armería, Madrid, inv. N-18). Fuente, Crooke y Navarrot, Juan Bautista (conde de Valencia de Don Juan) (1889): "Bilderinventar der Waffen, Rüstungen, Gewänder und Standarten Karl V. In der Armería Real zu Madrid [1]". En: Jahrbuch der Kunsthistorischen Sammlungen des Allerhöchsten Kaiserhauses, 10, Viena, pp. CCCLIII-CCCXCIX.

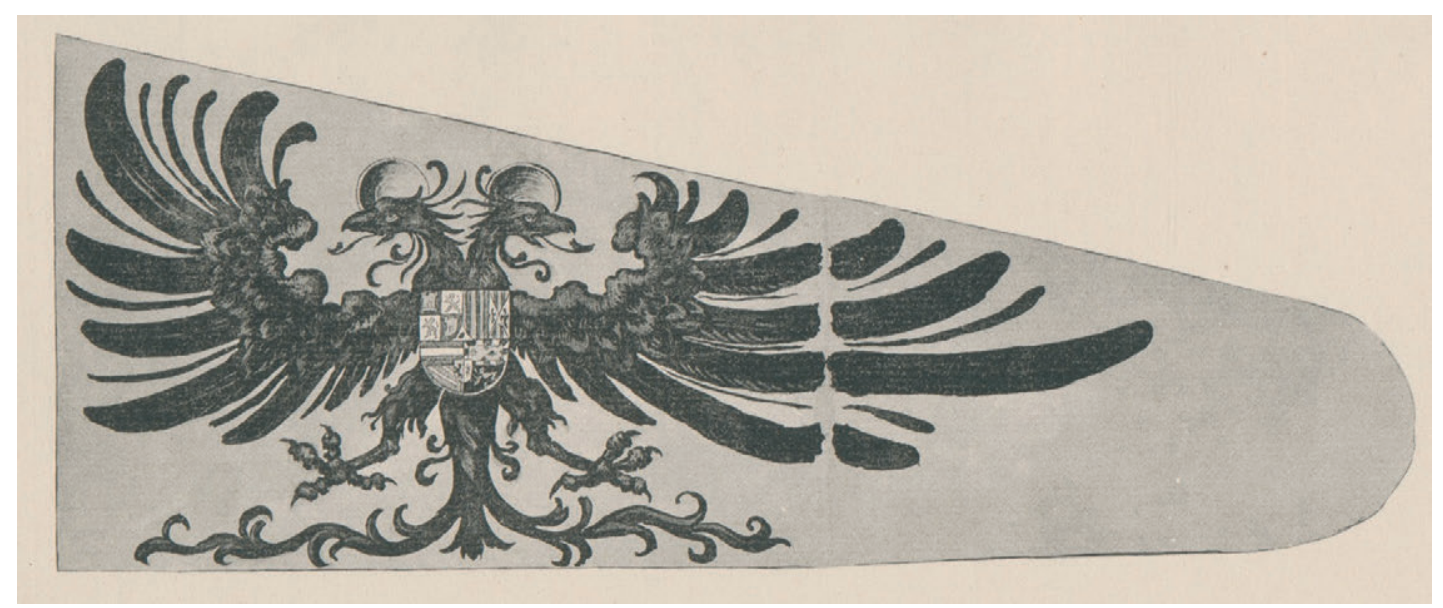

Fig. 7. Bandera con las armas imperiales. Del Inventario Iluminado (Real Armería, Madrid, inv. N-18). Fuente, Crooke y Navarrot, Juan Bautista (conde de Valencia de Don Juan) (1889): "Bilderinventar der Waffen, Rüstungen, Gewänder und Standarten Karl V. In der Armería Real zu Madrid [1]". En: Jahrbuch der Kunsthistorischen Sammlungen des Allerhöchsten Kaiserhauses, 10, Viena, pp. CCCLIII-CCCXCIX.

ciudad de Bolonia - con el mote Libertas-, banderas papales y de la universidad, entre otras. Uno de los escritos más importantes fue el del cronista Cornelio Agrippa, que recoge la presencia de estas banderas aludiendo entre las imperiales a la del pueblo de Roma -con los caracteres SPQR-, la del "romani imperii aquila" y la "Divi Georgii vexillum"56 (fig. 8).

56 Cornelio Agrippa, Caroli Quinti cum Hispaniarum tum duplicis Germaniae et Romanoru[m] Archiregis, utriusq[ue] [et] in Longobardorum regem, [et] in Romanorum Impertorem coronationis historia, Amberes, 1530, s/f. 


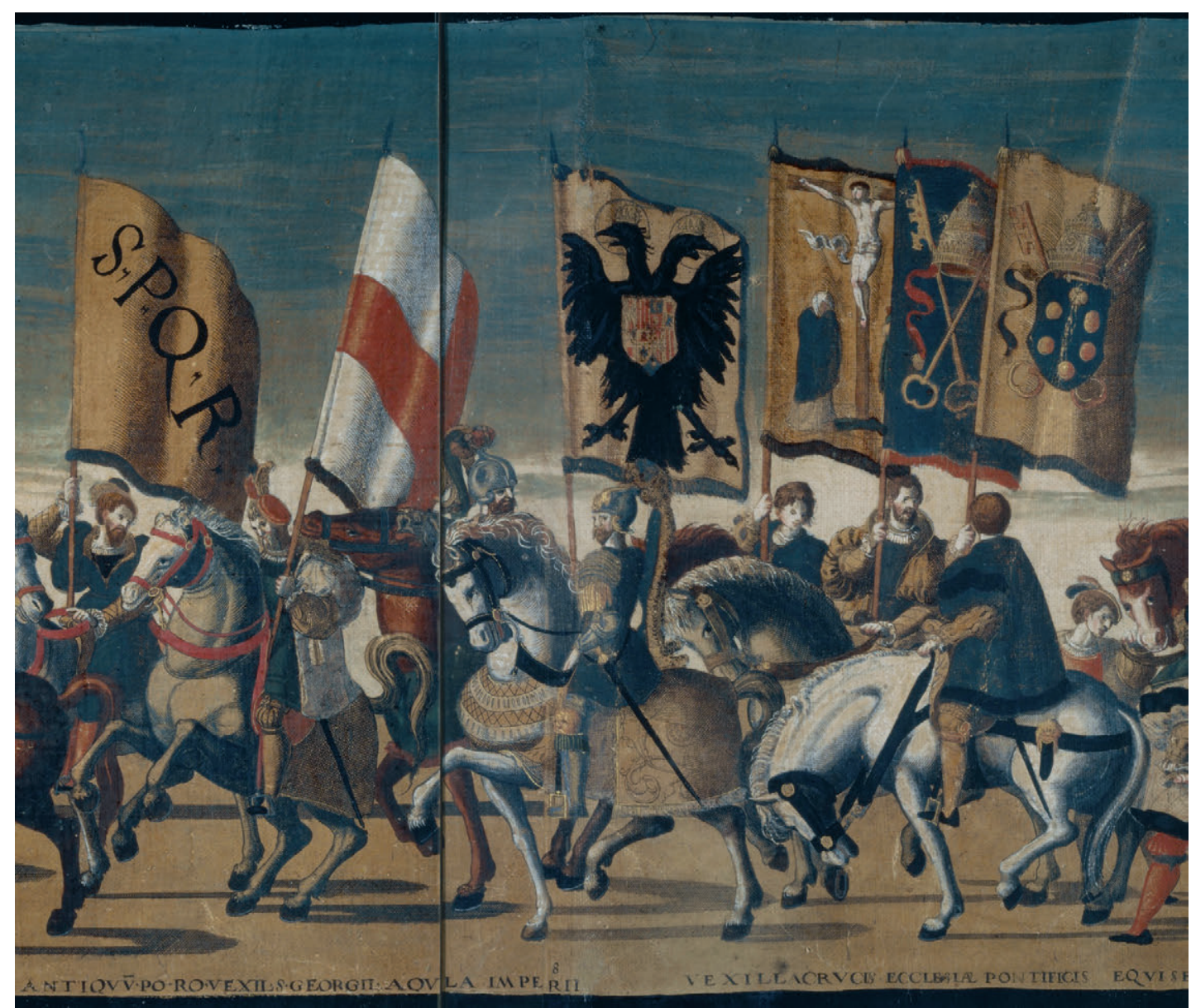

Fig. 8. Detalle de La procesión del Papa Clemente VII y el Emperador Carlos V después de la coronación en Bolonia, de N. Hogenberg, ca. 1530.

Es esta última bandera la que plantea más problemas de identificación. ¿Se trataba de una representación ecuestre del santo, al estilo de las banderas borgoñonas, o era por el contrario simplemente una cruz de gules sobre fondo de plata, que corresponde efectivamente con la bandera de San Jorge? En la serie de grabados que sobre el suceso realizara Hogenberg se representa esta última, al igual que en la serie anónima que muestra la entrada en la ciudad, impresa en Venecia en 1530. También algunas crónicas del momento indican la presencia de "la croce rossa in campo bianco", entre las banderas imperiales ${ }^{57}$. Sólo la serie grabada de Robert Péril muestra una enseña con el santo a caballo, alanceando al dragón, única referencia a que el estandarte de San Jorge mostrara la figura del caballero cristiano.

Al margen de su iconografía, lo que es significativo es la alusión al santo en los actos de Bolonia y que sirve para ejemplificar la importancia de su figura para el emperador, empleado como reflejo del soldado cristiano, como símbolo de la cruzada contra el Islam, y como recuerdo de su abuelo Maximiliano I y la orden de San Jorge ${ }^{58}$.

57 Vizzani, 2000: 73.

58 Maximiliano nombró caballeros de la orden en 1508 en Trento cuando fue proclamado como emperador electo (Wiesflecker-Friedhuber, 1997: 435), pero no podemos afirmar que Carlos V hiciera lo mismo en Bolonia. En 1521 la orden apenas contaba con 40 miembros (Wiesflecker-Friedhuber, 1997: 436). 
En la armería de Carlos V se guardaban banderas con esta iconografía así como banderas de fondo blanco con cruces rojas, alguna de las cuales pudo ser la empleada en Bolonia.

Si las banderas indicadas aparecen con alguna variación en todas las narraciones, sólo la crónica de Luigi Gonzaga, abundante en detalles, recoge la presencia de muchas otras en Bolonia ${ }^{59}$. Así, se refiere en primer lugar "il stendardo grande imperiale con l'aquila con do teste coronate di la corona imperiale" (la bandera con el águila bicéfala imperial), "il stendardo de' Romani" con las letras SPQR, "il stendardo di Alemania sì come Sua Maestà re di Germania con le armo della casa sua di Austria", otra con las armas de los reinos hispánicos "con le armi di Spagna", otra "delli paesi acquistati oltre le colonne di Hercole con la colonna in mano dipinti con il motto Plus Ultra", y por última una con las armas "delli regni di Napoli e Sicilia".

Conocemos al menos tres series de grabados de la coronación imperial de Bolonia. La más conocida es la realizada según ilustraciones de Nicolas Hogenberg, La procesión del Papa Clemente VII y el Emperador Carlos V después de la coronación en Bolonia, fechada hacia 1530 y que vio publicarse en varias ediciones con pequeñas diferencias entre unas y otras ${ }^{60}$, y de la que existen ejemplares coloreados. En ella aparece descrita la cabalgata triunfal posterior a la ceremonia de la coronación, sin olvidar las referidas banderas. Asimismo, la serie de Robert Péril Entrada triunfal del Emperador Carlos V y del Papa Clemente VII en Bolonia, publicada en Amberes en $1530^{61}$, recoge los hechos. La composición, semejante a la de Hogenberg en cuanto a la sucesión de los participantes en el cortejo, muestra también el despliegue de banderas con más detalle en algún caso, destacando no sólo las águilas bicéfalas del emperador sino también la divisa de las columnas de Hércules en la decoración de algunas trompetas.

Tal vez menos conocida es una obra impresa en Venecia en 1530, compuesta por dieciséis xilografías que tienen la particularidad de mostrar la entrada efectuada por el emperador en Bolonia antes de su coronación. Se trata de la Entrada de Carlos $V$ en Bolonia el 5 de noviembre de $1529^{62}$. En esta serie vemos banderas con los pedernales, llamas y aspas del Toisón de Oro; enseñas de los lansquenetes, que habitualmente mostraban franjas de diferentes colores y las aspas de San Andrés; una bandera con las armas imperiales, que aparecen también en las trompetas; y otra con "una crose rossa", el estandarte de San Jorge.

Está documentada la relación del pintor Jacques van Battele con estas banderas, pues realizó "une grande bannière impérialle qui contenoit quinze aulnes de taftaf, dorée aux deux costez de fin or", y además hizo "tailler et coudre la bannière de St. Georges, avec la bannière impèrialle" 63 . Tal vez con los actos de Bolonia pueda relacionarse además el pago por veinticuatro banderas de trompetas con las armas del emperador, seis guiones para portar tras el césar, ocho escusones para los atabales de España con las armas imperiales, además de seis cotas de armas con las mismas, y la pintura de dos arneses de la morisca y una barda ${ }^{64}$.

Entre las victorias del emperador, la campaña de Túnez de 1535 fue sin duda un episodio muy significativo, especialmente por el componente religioso del triunfo sobre el Islam. Este hecho alcanzó una gran repercusión en las artes, sobre todo gracias a la serie de tapices tejida entre 1548 y 1554 según diseños de Vermeyen en el taller de Wilhelm de Pannemaker ${ }^{65}$.

\footnotetext{
59 Gonzaga, 2000: 141.

${ }^{60}$ Stirling Maxwell, 1875. Un ejemplar se conserva en la BNE, signatura INVENT/42179-INVENT/42218. Una edición moderna de este en La Coronación imperial de Carlos V, Madrid, 1958.

${ }^{61}$ Se conservan ejemplares en la Albertina de Viena (K.S.E-108 Cimelien Fach I, 18) y en el Museo Plantin-Moretus de Amberes (MPM.V.VI.01.003). Criado Mainar, 2000b: 257-274.

${ }^{62}$ Una edición en la British Library, General Reference Collection 134.g.10 (171-186). También un ejemplar en el British Museum, referencia 1862,0208.5. Criado Mainar, 2000a: 247-256, recoge un ejemplar conservado en Florencia, Gabinete Disegni e Stampe degli Uffizi, signatura 27-ST. SC.

${ }^{63}$ Archives Départementales du Nord (ADN), Lille, B. 3350, fol. 172 v. La noticia fue publicada en Finot, 1892: 282 .

${ }^{64}$ ADN, Lille, B. 3350, fol. 172 r. Finot, 1892: 282.

${ }^{65}$ Es muy abundante la bibliografía acerca de esta magnífica serie. Dos de las más recientes referencias: Checa, 2012: 153-179. Haag/Schmitz, 2013.
} 


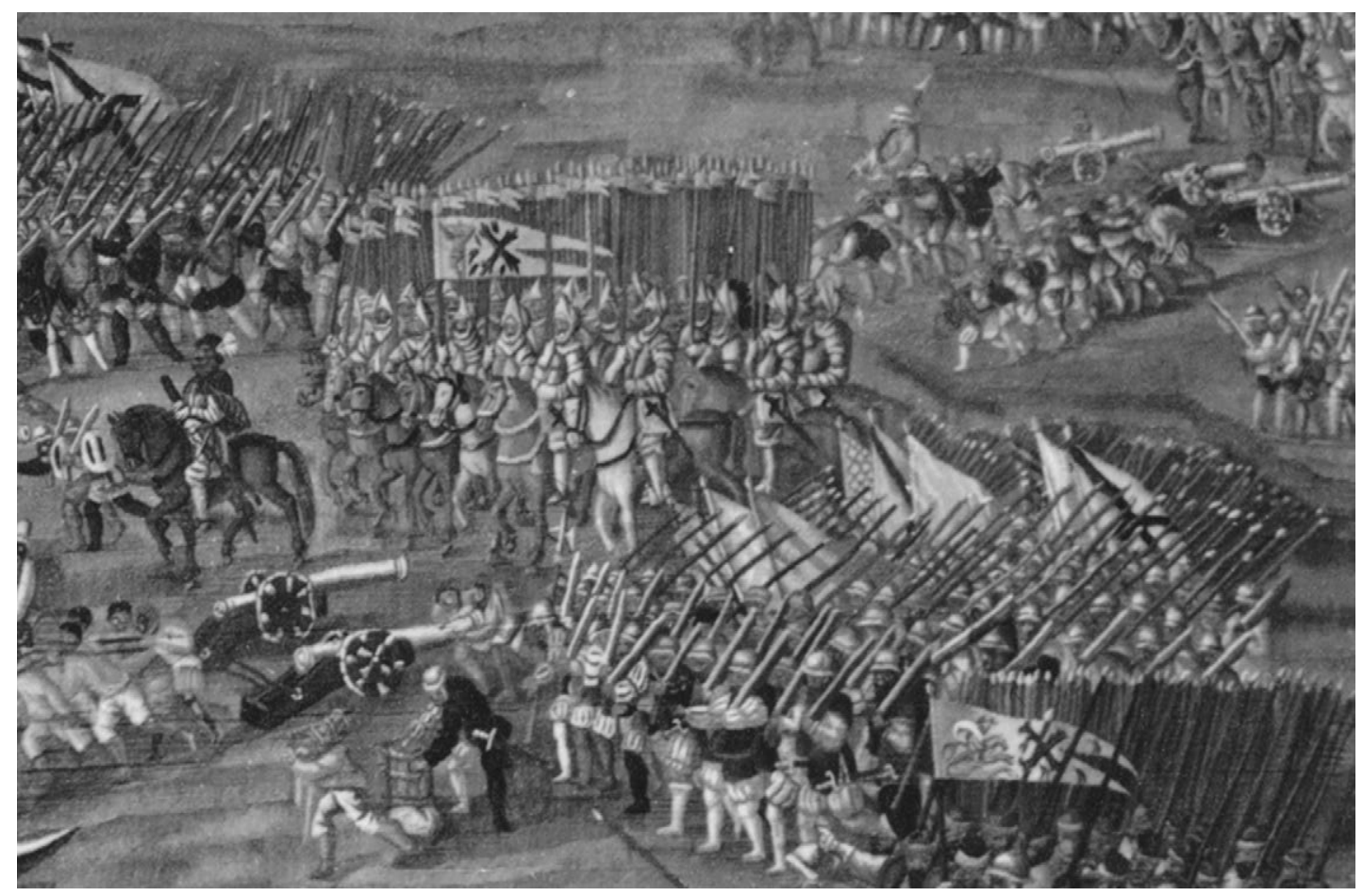

Fig. 9. Detalle del paño Toma de Túnez (Patrimonio Nacional, PN. TA-13/9). Diseños de Jan Cornelis Vermeyen, tejido en el taller de Pannemaker, 1549-1554.

En los paños ${ }^{66}$ podemos ver algunas de las banderas que el emperador empleó en su campaña. Así, se observa la presencia de las aspas de Borgoña, Santiago a caballo, también un crucificado junto a la cruz de San Andrés ${ }^{67}$ (fig. 9), y se aprecian también las pequeñas banderas de fondo amarillo sobre las que campean las águilas imperiales que decoraban las trompetas. Además, en el paño segundo - La reunión de las tropas en Barcelona- aparece el estandarte de la Purísima Concepción, motivo repetido en una bandera de caballería que muestra el cuarto paño -Ataque a la Goleta- (fig. 10).

Entre las piezas que se custodiaban en la armería imperial de Valladolid en 1542, se encontraban varias de estas banderas empleadas en Túnez. Así, se señalan: "Una bandera de tafetán colorado a donde está pintado un Crucifixo que se llevó a Túnez", y "Otra bandera pequeña de damasco y tafetán colorado a donde está pintada una Nuestra Señora y un San Jorge que también se llevó a Túnez", reforzando la idea de cruzada a la que sus ancestros vincularon la imagen del santo. Con estas ideas pueden relacionarse también las dos banderas asociadas con Viena -sin duda con la campaña contra el Turco de 1532 y la entrada triunfal del emperador en esa ciudad en septiembre- que recoge el inventario ${ }^{68}$.

Todas estas piezas que hemos mencionado pueden identificarse en las relaciones documentales de la armería de Valladolid fechadas en 1542 y 1558, y que ahora hemos dado a conocer.

\footnotetext{
66 Se conservan en Patrimonio Nacional, PN,TA-13/1-12 (sin los paños 13/8 y 13/11). Junquera de Vega/Herrero Carretero, 1986: 73-92. Se realizó una copia en el siglo XVIII, que permite conocer los paños perdidos en la serie original: Herrero Carretero, 2000: 249-277. Sobre los cartones, que se custodian en el Kunsthistorisches Museum de Viena, Haag/Schmitz, 2013.

${ }^{67}$ González García, 2007: 30.

68 Apéndice documental, documento 1.
} 


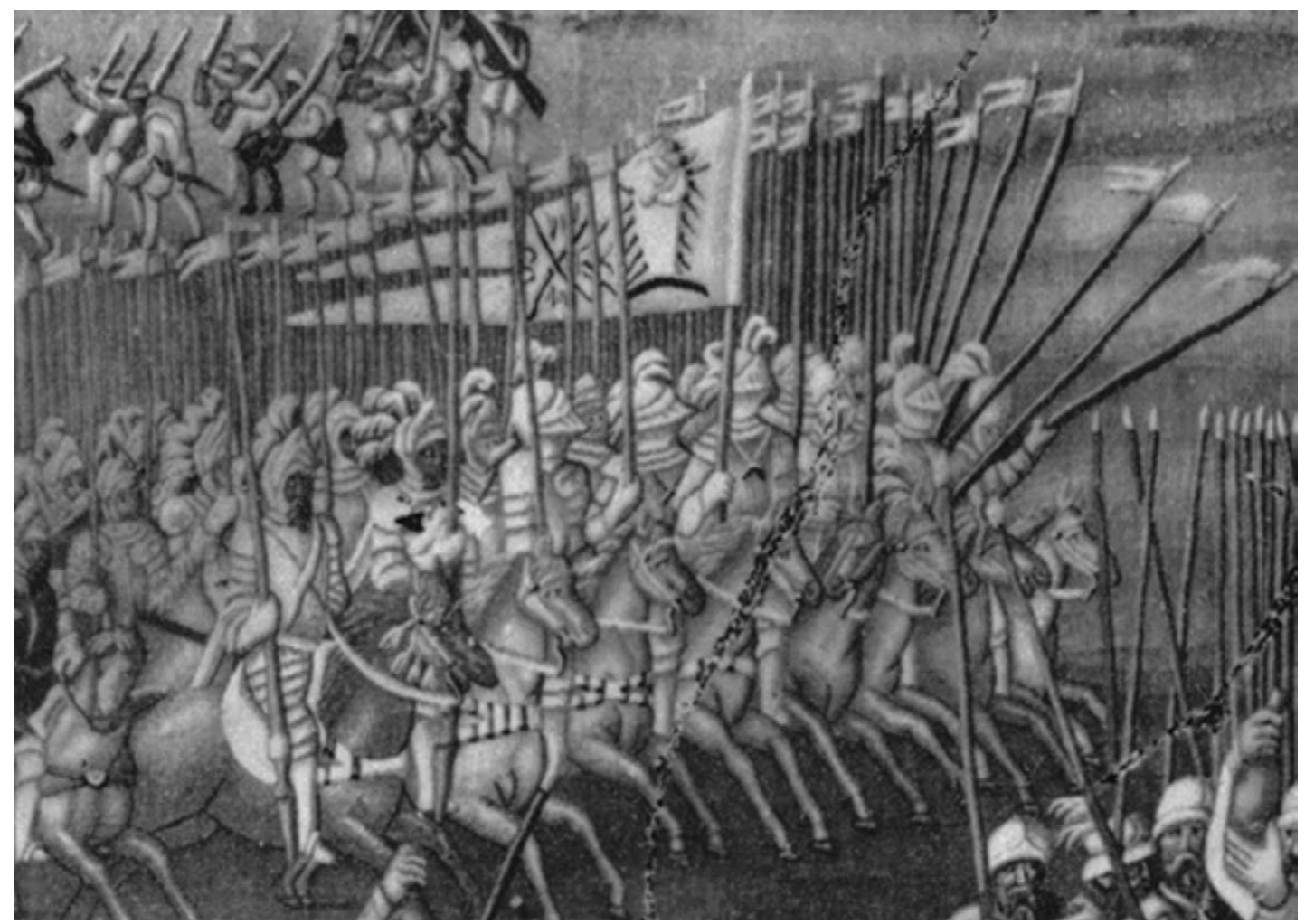

Fig. 10. Detalle del paño Ataque a la Goleta (Patrimonio Nacional, PN. TA-13/4). Diseños de Jan Cornelis Vermeyen, tejido en el taller de Pannemaker, 1549-1554.

Gracias a estos datos recuperamos la memoria de las banderas que Carlos V atesoró, y que pasaron después a poder de Felipe II como reliquias familiares, reflejo de actos y campañas de gran importancia simbólica para el linaje y que reunían, en la extensión de una rica tela pintada, todo un programa iconográfico de poder y magnificencia.

\section{APÉNDICE DOCUMENTAL}

Documento 1: Lo que está en la armería de su majestad que está en Valladolid, a treinta de junio de mill y quinientos y quarenta y dos. Archivo Histórico Provincial de Valladolid (AHPVa), protocolos notariales (prot.), leg. 106, fol. 1004-1005.

En otra alaçena de las banderas.

Una bandera de tafetán colorado a donde está pintado un crucifixo que se llevó a Túnez.

[Margen: maese Juan la llevó] Otra bandera pequeña de damasco y tafetán colorado a donde está pintada una nuestra Señora y un San Jorge que también se llevó a Túnez.

[Margen: maese Juan] Otra bandera grande de tafetán amarillo a donde están pintados un Santiago y Sant Andrés y Sant Jorge, que fue hecha para tna nave Viena nuevo.

Otra bandera de tafetán amarillo adonde está pintado un crucifixo y las armas de su magestad que fue hecho para Viena nuevo.

[Margen: maese Juan la llevó] Otra bandera de tafetán amarillo adonde están pintados Sant Andrés, Sant Jorge y Santiago, que sirbió ante a Aes [sic] en Francia. 
Otra bandera grande de tafetán amarillo colorado y blanco adonde está pintado Santiago que fue fecha para el coronamiento en nuestra Señora de Aes [sic].

Otra bandera grande de tafetán amarillo colorado y blanco y en ella está pintado San Xpval que fue fecha para el coronamiento en nuestra Señora de Aes [sic].

Otra bandera pequeña de tafetán amarillo blanco y colorado adonde está pintado un Sant Andrés que fue hecha para el coronamiento de nuestra Señora de Aes [sic].

Otra bandera redonda de damasco negro con las armas del emperador que fue hecha para el coronamiento de Aes [sic].

Yten otra bandera quadrada de damasco negro con las armas del emperador frangeada de colorado amarillo y blanco.

Yten otra bandera de damasco colorado y blanco con una cruz de Rodas frangeada de blanco y colorado.

Yten çinco cornetas de archeros de damasco colorado amarillo y blanco, a saber en la una está pintado Santiago, y en la otra Sant Juan Baptista, y en la otra Sant Pedro, y en la otra Sant Xpual, y en la otra Santo Thomás.

Yten una bandera quadrada [roto] están pintadas las armas de su magestad.

Yten dos banderas viejas de trompetas.

Documento 2: Inventario de la armería de Carlos V en Valladolid, 1558. AHPVa, prot., leg. 106, fols. 976-977 v.

Vanderas las que estauan a cargo de Peti Juan y otras que binieron a la postre con su magestad que todas están aquí:

Una bandera de tafetán amarillo con un Santiago y letra de Plus Hultra con una franja de seda amarilla.

Otra bandera de tafetán amarilla con unas columnas de Plus Hultra y un San Pedrobal [sic] pintado blanco y colorado.

Otra de tafetán amarillo las armas ynperiales pintadas y un crucifijo con franjas de seda.

Otras de tafetán colorado un cruçifijo pintado en ella y con franjas de seda y colorada.

Una bandera de galera pintada campo amarillo pintadas las armas ymperiales.

Otra que tiene un Sant Andrés pintado en ella con Plus Hultra campo blanco y amarillo plateado y dorado.

Otra bandera de galera de damasco blanco una cruz colorada por ella.

Una corneta de cavallos ligeros donde están pintadas las armas de su magestad de damasco carmesí y dorado.

Otra bandera donde está pintada un águyla ynperial campo dorado.

Otra como esta que son entramas de trompeta también campo dorado.

Las banderas que vinieron a la postre.

Çinco banderas de lanças dos rrojas digo tres y dos negras de tafetán pintadas.

Dos guiones de damasco pintados.

Una bandera de tafetán colorado donde está pintado señor San Jorge y Santiago.

Otra bandera como esta.

Una bandera destandarte blanco y rroxo con una cruz colorada por ella.

Una bandera ymperial con una águila negra en ella.

Una bandera de tafetán colorado que tiene una nuestra Señora, Santiago y Sant Andrés.

Otra bandera de tafetán colorado que tiene un cruçifixo.

Un estandarte grande donde está señor Santiago y una águila ymperial de tafetán amarillo.

Dos cotas darmas pintadas sobre rraso negro de rreyes darmas.

Otra cota darmas como estas.

Tres banderas de lanças coloradas pequeñas.

Y otras pequeñas con unos santos en ellos tres.

Un libro do están pintadas las harmas de su magestad de papel. 


\section{BIBLIOGRAFÍA}

Azcárate, José María de (1982): Datos histórico-artísticos de fines del siglo XV y principios del XVI. En: Colección de documentos para la Historia del Arte en España. Madrid-Zaragoza: Obra Social de la Caja de Ahorros de Zaragoza, Aragón y Rioja, t. II.

Azcárate, José María de (1988): Alonso Berruguete. Salamanca: Publicaciones del Colegio de España.

Borrás Gualis, Gonzalo M./Criado Mainar, Jesús (dirs.) (2000): La imagen triunfal del emperador: la jornada de la coronación imperial de Carlos V en Bolonia y el friso del ayuntamiento de Tarazona (cat.-exp.). Madrid: Sociedad Estatal para la Conmemoración de los Centenarios de Felipe II y Carlos V.

Boulton, Jonathan (2006): "The order of the Golden Fleece and the Creation of Burgundian National Identity". En: Boulton, Jonathan/Veenstra, Jan van (eds.): Ideology of Burgundy. The Promotion of National Consciousness, 1364-1565. Leiden: Brill, pp. 21-97.

Canellas López, Ángel (1966-1967): "Leyenda, culto y patronazgo en Aragón del señor San Jorge, mártir y caballero". En: Cuadernos de Historia Jerónimo Zurita, 19-20, Zaragoza, pp. 7-22.

Checa, Fernando (2007): “De Maximiliano I a Fernando I. La nueva imagen del poder y de la guerra”. En: Checa, Fernando (dir.): Durero y Cranach. Arte y Humanismo en la Alemania del Renacimiento (cat.-exp.). Madrid: Museo Thyssen-Bornemisza y Fundación Caja Madrid, pp. 398-399.

Checa, Fernando (2012): Tesoros de la Corona de España. Bruselas: Fonds Mercator.

Criado Mainar, Jesús (2000a): “Entrada de Carlos V en Bolonia el 5 de noviembre de 1529”. En: Borrás Gualis, Gonzalo M./Criado Mainar, Jesús (dirs.): La imagen triunfal del emperador: la jornada de la coronación imperial de Carlos $V$ en Bolonia y el friso del ayuntamiento de Tarazona (cat.-exp.). Madrid: Sociedad Estatal para la Conmemoración de los Centenarios de Felipe II y Carlos V, pp. 247-256.

Criado Mainar, Jesús (2000b): "La gran cabalgata de Bolonia”. En: Borrás Gualis, Gonzalo M./Criado Mainar, Jesús (dirs.): La imagen triunfal del emperador: la jornada de la coronación imperial de Carlos V en Bolonia y el friso del ayuntamiento de Tarazona (cat.-exp.). Madrid: Sociedad Estatal para la Conmemoración de los Centenarios de Felipe II y Carlos V, pp. 257-274.

Criado Mainar, Jesús (2006): "La coronación imperial de Carlos V: el friso del ayuntamiento de Tarazona”. En: Colomer, José Luis/Serra Desfilis, Amadeo (eds.): España y Bolonia. Siete siglos de relaciones artísticas y culturales. Madrid: Centro de Estudios de Europa Hispánica, pp. 103-117.

Crooke y Navarrot, Juan Bautista, conde de Valencia de Don Juan (1889): "Bilderinventar der Waffen, Rüstungen, Gewänder und Standarten Karl V. In der Armería Real zu Madrid [1]”. En: Jahrbuch der Kunsthistorischen Sammlungen des Allerhöchsten Kaiserhauses, 10, Viena, pp. CCCLIII-CCCXCIX.

Crooke y Navarrot, Juan Bautista, conde de Valencia de Don Juan (1890): "Bilderinventar der Waffen, Rüstungen, Gewänder und Standarten Karl V. In der Armería Real zu Madrid [2]”. En: Jahrbuch der Kunsthistorischen Sammlungen des Allerhöchsten Kaiserhauses, 11, Viena, pp. CCXLII-CCCXXIV.

Crooke y Navarrot, Juan Bautista, conde de Valencia de Don Juan (1898): Catálogo histórico-descriptivo de la Real Armería de Madrid. Madrid: Estab. Tip. Sucesores de Rivadeneyra.

Domínguez Casas, Rafael (1993): Arte y etiqueta de los Reyes Católicos. Artistas, residencias, jardines y bosques. Madrid: Alpuerto.

Domínguez Casas, Rafael (2006): "Estilo y rituales de corte". En: Zalama, Miguel Ángel/Vandenbroeck, Paul (dirs.): Felipe I el Hermoso. La belleza y la locura. Madrid: Centro de Estudios de Europa Hispánica, pp. 89-104.

Domínguez Casas, Rafael (2010): "Exequias borgoñonas en tiempos de Juana I de Castilla". En: Zalama, Miguel Ángel (dir.): Juana I de Tordesillas: su mundo, su entorno. Valladolid: Grupo Página, pp. 259-286.

Deuchler, Florens (1963): Die Burgunderbeute: Inventar der Beutestücke aus den Schlachten von Grandson, Murten und Nancy 1476/1477. Berna: Stämpfli.

Eisman Lasaga, Carmen (1994): "Los tejidos". En: Pita Andrade, José Manuel (coord.): El libro de la Capilla Real de Granada. Granada: Ediciones Miguel Sánchez, pp. 169-175.

Fernández de Córdova Miralles, Álvaro (2012): "Las divisas del rey: escamas y ristres en la corte de Juan II de Castilla". En: Reales Sitios, 191, Madrid, pp. 22-37.

Ferrandis Torres, José (1948): Datos documentales para la historia del arte español. Madrid: CSIC, III.

Finot, Jules (1892): Inventaire Sommaire des Archives Départementales Antérieures a 1790. Nord. Lille: Imprimerie de L. Danel, vol. 7 .

Gonzaga, Luigi (2000): "Cronaca del soggiorno di Carlo V in Italia e della sua incoronazione in Bologna". En: Righi, Roberto (ed.): Carlo V a Bologna: cronache e documenti dell'incoronazione (1530). Bolonia: Costa Editore, pp. 117143.

González García, Juan Luis (2007): “Pinturas Tejidas. La Guerra como Arte y el Arte de la Guerra en Torno a la Empresa de Túnez (1535)”. En: Reales Sitios, 174, Madrid, pp. 24-47.

Haag, Sabine/Schmitz-von Ledebur, Katja (2013): Kaiser Karl V. erobert Tunis: Dokumentation eines Kriegzuges in Kartons und Tapisserien. Viena: Kunsthistorisches Museum.

Herrero Carretero, Concepción (2000): Catálogo de tapices del Patrimonio Nacional. III. Siglo XVIII. Reinado de Felipe $V$. Madrid: Patrimonio Nacional.

Heusch, Hermann (1960): "Le Sacre de Charles Quint à Aix-la-Chapelle”. En: Jacquot, Jean (coord.): Les Fêtes de la Renaissance, II: Fêtes et cérémonies au temps de Charles Quint, París: CNRS, pp. 161-168. 
Junquera de Vega, Paulina/Herrero Carretero, Concepción (1986): Catálogo de tapices del Patrimonio Nacional. Volumen I: siglo XVI. Madrid: Patrimonio Nacional.

Koldeweij, Jos (2013): “A good example to follow. The reliquaries of Charles the Bold, John of Lannoy, and John Bastard of Cleves”. En: Blockmans, Wim et al (eds.): Staging the Court of Burgundy. Turnhout: Brepols, pp. 229-240.

La Marche, Olivier de (1888): Mémoires d'Olivier de La Marche, maître d'hôtel et capitaine des gardes de Charles le Téméraire. París: Librairie Renouard, t. IV.

Mäder, Beat/Heinz, Matilde (eds.) (1969): Die Burgunderbeute und Werke burgundischer Hofkunst (cat.-exp.). Berna: Bernisches Historisches Museum

Mäder, Peter M. (1994): "Ein 'fast' zerfallenes Burgunderbanner: Untersuchungs-, Konservierungs- und Restaurierungsmöglichkeiten am Beispiel einer Fahne aus der Burgunderbeute”. En: Zeitschrift für schweizerische Archäologie und Kunstgeschichte, 51, Heft 3, Zúrich, pp. 265-272.

Madersbacher, Lukas (1992a): “El emperador Maximiliano I como paladín cristiano". En: Checa, Fernando (dir.): Reyes y Mecenas. Los Reyes Católicos-Maximiliano I y los inicios de la Casa de Austria en España (cat.-exp,). Toledo: Electa, p. 436.

Madersbacher, Lukas (1992b): "El carro triunfal”. En: Checa, Fernando (dir.): Reyes y Mecenas. Los Reyes CatólicosMaximiliano I y los inicios de la Casa de Austria en España (cat.-exp,). Toledo: Electa, pp. 454-455.

Marti, Susan (2009): "Fragments of cornets". En: Marti, Susan/Borchert, Till-Holger/Keck, Gabriele (eds.): Charles the Bold (1433-1477). Splendour of Burgundy. Bruselas: Mercatorfonds, p. 324.

Martínez López, Rocío (2013): "El cenotafio de Maximiliano I: la memoria dinástica, política y territorial a través de los monumentos funerarios reales". En: Aldea Celada, José Manuel et al. (coords.): Los lugares de la Historia. Salamanca: Hergar Ediciones Antema, pp. 481-509.

Michael, Nicholas/Embleton, Gerry A. (1983): Armies of medieval Burgundy 1364-1477. Londres: Osprey Publishing.

Nieto Alcaide, Víctor/García Morales, María Victoria (2004): "Santiago y la monarquía española: orígenes de un mito de Estado". En: Santiago y la Monarquía de España (1504-1788). Madrid: Sociedad Estatal de Conmemoraciones Culturales, pp. 33-51.

Nieto Soria, José Manuel (1993): Ceremonias de la realeza. Propaganda y legitimación en la Castilla Trastámara. Madrid: Nerea.

Onghena, M. J. (1959): De iconografie van Philips de Schone. Bruselas: Palais des Académies, 2 vols.

Pascual Molina, Jesús F. (2013): "La armería de Carlos V en Valladolid. Historia de una colección imperial”. En: Checa, Fernando (dir.): Museo Imperial. El coleccionismo artístico de los Austrias en el siglo XVI. Madrid: Fernando Villaverde Ediciones, pp. 81-101.

Pokorny, Erwin (1992a): "San Jorge a caballo". En: Checa, Fernando (dir.): Reyes y Mecenas. Los Reyes CatólicosMaximiliano I y los inicios de la Casa de Austria en España (cat.-exp,). Toledo: Electa, pp. 437-438.

Pokorny, Erwin (1992b): "Maximilian I. als heiliger Georg”. En: Hispania-Austria-Die Katholischen Könige Maximilian I. und die Anfänge der Casa de Austria in Spanien (cat.-exp.). Milán: Electa, p. 347.

Redondo Cantera, María José (2013): "Berruguete, pintor del rey". En: Hoyos Alonso, Julián (ed.): Alonso Berruguete: su obra e influencia. Palencia: Diputación, pp. 49-89.

Righi, Roberto (ed.) (2000): Carlo V a Bologna: cronache e documenti dell 'incoronazione (1530). Bolonia: Costa Editore.

Sandoval, Prudencio de (1604): Primera parte de la historia y hechos del emperador Carlos V. Valladolid: Sebastián de Cañas.

Schauerte, Thomas U. (2001): Die Ehrenpforte für Kaiser Maximilian I. Dürer und Altdorfer im Dienst des Herrschers. Múnich: Deutscher Kunstverlag.

Schütz, Karl (1992): "Maximiliano y el arte". En: Checa, Fernando (dir.): Reyes y Mecenas. Los Reyes Católicos-Maximiliano I y los inicios de la Casa de Austria en España (cat.-exp,). Toledo: Electa, pp. 233-251.

Senn, Matthias (1994): "Die Fahnen im Schweizerischen Landesmuseum: Geschichte des Sammlungsbestandes; Hinweise auf bisherige Konservierungen und Restaurierungen". En: Zeitschrift für schweizerische Archäologie und Kunstgeschichte, 51, Heft 3, Zúrich, pp. 229-236.

Stirling Maxwell, William (1875): The Procession of Pope Clement VII and the Emperor Charles VAfter the Coronation at Bologna. Edimburgo: Edmonston and Douglas.

Vital, Laurent (1952): "Relación del primer viaje de Carlos V a España”. En; García Mercadal, José (ed.) (1952): Viajes de extranjeros por España y Portugal. Desde los tiempos más remotos hasta fines del siglo XVI. Madrid: Aguilar, pp. 626-788.

Vizzani, Pompeo (2000): "Dieci libri delle Historie della sua patria". En: Righi, Roberto (ed.): Carlo V a Bologna: cronache e documenti dell'incoronazione (1530). Bolonia: Costa Editore, pp. 58-76.

Wescher, Herta (1949): "Flags". En: Ciba Review, 77, Basilea, pp. 2806-2830.

Wiesflecker-Friedhuber, Inge (1997): "Maximilian I. und der St. Georgs-Ritterorden”. En: Nikolasch, Franz (ed.): Studien zur Geschichte von Millstatt und Kärnten. Vorträge der Millstätter Symposien 1981 bis 1995. Kagenfurt: Verlag des Geschichtsvereines für Kärnten, pp. 431-454.

Zalama, Miguel Ángel/Domínguez Casas, Rafael (1995): "Jacob van Laethem, pintor de Felipe el Hermoso y Carlos V: precisiones sobre su obra". En: Boletín del Seminario de Estudios de Arte y Arqueología, LXI, Valladolid, pp. 347-358. 


\section{FUENTE DE LA FIGURAS}

Fig. 1: http:/emp-web-45.zetcom.ch/eMP/eMuseumPlus?service=direct/1/ResultDetailView/result.inline.lightbox. t1.collection_lightbox. $\$$ TspTitleImageLink.link\&sp=13\&sp=Sexhibition\&sp=SfieldValue \&sp=0\&sp=0\&sp=3\&sp=Sde tailView\&sp=0\&sp=Sdetail\&sp=0\&sp=T\&sp=0\&sp=Slightbox_2x3\&sp=0\&sp=F\&sp=Scollection\&sp=18922.

Fig. 2: Bibliothèque numérique de l'INHA - Bibliothèque de l'Institut National d'Histoire de l'Art (Paris), collections Jacques Doucet.

Fig. 3: Bibliothèque numérique de l'INHA — Bibliothèque de l'Institut National d'Histoire de l'Art (Paris), collections Jacques Doucet.

Fig. 4: Heidelberg University Library, http://digi.ub.uni-heidelberg.de/diglit/jbksak1889a/0398.

Fig. 5: Heidelberg University Library, http://digi.ub.uni-heidelberg.de/diglit/jbksak1889a/0402.

Fig. 6: Heidelberg University Library, http://digi.ub.uni-heidelberg.de/diglit/jbksak1889a/0400.

Fig. 7: Heidelberg University Library, http://digi.ub.uni-heidelberg.de/diglit/jbksak1889a/0404.

Fig. 8: Digital image courtesy of the Getty's Open Content Program, The Getty Research Institute, Los Ángeles.

Fig. 9: Digital image courtesy of the Getty's Open Content Program, The Getty Research Institute, Los Ángeles.

Fig. 10: Digital image courtesy of the Getty's Open Content Program, The Getty Research Institute, Los Ángeles.

Fecha de recepción: 14-V-2015

Fecha de aceptación: 24-IX-2015 